\title{
Beyond Voice: Conceptualizing Children's Agency in Domestic Violence Research Through a Dialogical Lens
}

\author{
Anita Morris' ${ }^{D}$, Cathy Humphreys', and Kelsey Hegarty ${ }^{2}$
}

\begin{abstract}
Children who live in households where domestic violence is occurring have been variously described in the literature over time as silent witnesses, witnesses, a cohort who is "exposed" to the violence, and more recently, as individual victim survivors and active agents in their own right, each with their own lived experience of violence.

Research methodologies in this arena have shifted from adult-focused measurements of the impacts of domestic violence on children to more qualitative attempts to understand the experience from the child's perspective. In doing so, there have been notions of giving "voice to the voiceless" and doing no further harm through a desire to protect children from exposure. However, the relational framing of children's voices and recognition and enabling of children's agency is less evolved in research and professional interventions.

A study undertaken in Australia researched with a primary care population of 23 children and 18 mothers, children's experiences of safety and resiliency in the context of domestic violence. The findings of the research were realized using qualitative research methods with children and the analytical framing of hermeneutical phenomenology, ethics of care and in particular dialogical ethics, to draw practical understanding and application in health care settings.

This article aims to demonstrate how the analytical methodology chosen was applied in the research process and reveals the elements required for children to experience agency in navigating their relationships in an unsafe world, while learning about themselves. It draws upon understandings of the child's relational context and introduces a model of children's agency, which may have applicability for domestic violence policy and practice settings.
\end{abstract}

\section{Keywords}

hermaneutic phenomenology, feminist research, interpretive phenomenology, methods in qualitative inquiry, ethical inquiry

Date received: September 4, 2019. Received revised January 8, 2020; Accepted: July I3, 2020

\section{Introduction}

The field of qualitative domestic violence research with children, grounded in hallmark studies nearly two decades ago (McGee, 2000; Mullender et al., 2002), has garnered increased recognition of the role of child agency and the contextual factors that frame child voice in research and in some professional interventions (Callaghan et al., 2018; Ellife \& Holt, 2019; Katz, 2016; Øverlien, 2016). Within this milieu, primary care research with children that can support policy and practice responses which focus on children's safety and resilience, are notably absent (Feder et al., 2009; Houghton, 2015; Howarth et al., 2018; McMillan et al., 2013, Taft et al., 2004).

To address the research gap, this article focuses on the methodology and findings of a qualitative study undertaken with 23 children and 18 mothers in Australia, known as the "Safety and Resiliency At Home" (SARAH) project. The aim was to understand children's experiences of safety and resiliency in the context of domestic violence to inform health interventions for children. The term "domestic violence" is used throughout the paper to reflect the broad impacts and experiences of all members of a family when a perpetrator,

\footnotetext{
'University of Melbourne, Australia

${ }^{2}$ University of Melbourne \& Royal Women's Hospital, Australia
}

Corresponding Author:

Anita Morris, University of Melbourne, Melbourne, Victoria 3053, Australia. Email: a.morris@unimelb.edu.au 
International Journal of Qualitative Methods

predominantly a male partner, father or step-father uses coercive and controlling behaviors toward his female partner or expartner (often referred to as intimate partner violence) and directly or indirectly toward the children.

To inform and progress the field of domestic violence research with children the SARAH project used ethical childcentred research methods (Morris et al., 2012) and aligned with this approach, applied an interpretive analysis through hermeneutic phenomenology (Van Manen, 1990) and the moral theories of ethics of care and dialogical ethics (Held, 2006; Koehn, 1998; Noddings, 2003). The methodology relied upon situating the research in rich history that has moved beyond adultfocused quantitative research about children, to child-focused qualitative endeavor with and for children (Callaghan, 2018; Eliffe \& Holt, 2019; Øverlien, 2016).

\section{Background}

It is clear that defining children and their experiences of domestic violence has proved troublesome (Holden, 2003; Laing, 2000; Overlien, 2010). Children have been referred to as "silent victims" (Groves et al., 1993; Kolar \& Davey, 2007) despite their willingness to talk and provided they feel safe and have the support of someone they trust (McGee, 2000; Mullender et al., 2002). Children have been called the "forgotten" (Bergström, 1983; Elbow, 1982) or "hidden" (Warrier et al., 2002) victims.

The nature or extent of a child's experience has frequently been referred to as "witnessing" the violence (Callaghan, 2018; Kitzmann et al., 2003) which can inadvertently focus attention on a child's physical presence during violent episodes, rather than on the more pervasive, damaging and chronic trauma of living with violence (Perry, 2001). Describing children's "exposure" to violence (Eriksson \& Näsman, 2010; Olaya et al., 2010) is thought to be less prescriptive about what a child has seen, heard, felt or known. In the Australian context, this has resulted in minimal acknowledgment and support for such children (Noble-Carr et al., 2019). However, researchers argue a more holistic understanding when children are described as "experiencing" or "living with" domestic violence; terms more often used in qualitative research that seeks the child's perspective (Broberg et al., 2010; Buckley et al., 2007; Stanley et al., 2011).

A now expansive body of research evidence including significant meta-analyses (Edleson, 1999; Evans et al., 2008; Holt et al., 2008; Kitzmann et al., 2003), has confirmed the sad reality that children from violent homes experience a range of trauma-inducing events which include constant fear and vigilance, being involved in violent events and living through the upheaval and aftermath that follows. They are also predisposed to potentially multiple forms of abuse such as child maltreatment, sexual abuse, stalking, bullying, abuse by siblings and other crime, referred to as "poly-victimization" (Finkelhor et al., 2011). These multiple or overlapping forms of abuse have been found to exacerbate or expose children to future victimization and vulnerability to adversity. Domestic violence has also been found to contribute to a wide range of physical, social and emotional problems for these children (Bair-Merrit et al., 2006; Bedi \& Goddard, 2007; Holt et al., 2008).

Qualitative research that sought children's perspectives on domestic violence has been undertaken in Norway (Överlien \& Hydén 2009), the Republic of Ireland (Buckley et al., 2007; Eliffe \& Holt, 2019; Hogan \& O'Reilly, 2007), the United States (DeBoard-Lucas \& Grych, 2011), the United Kingdom (Callaghan, 2018; Katz, 2019; Stanley et al., 2010) and Australia (Bagshaw et al., 2010). Research methods have moved beyond interviews and focus groups, to include more creative and interactive methods such as photos and digital story-telling (Callaghan et al., 2018; Lamb et al., 2018). Lamb and colleagues' (2018) research focused on what children and young people wanted their fathers to understand about their experiences and what they expected fathers to do to repair the fatherchild relationship. The products of the research, children's digital stories, can be used in men's behavior change programs to effectively bring the child's experience and message into the room. Methods that involve co-creation of research products facilitate children's agency in the meaning-making of their experience as well as in the contribution children can make to social policy and practices (Lamb et al., 2018).

It is important to note that domestic violence has been described as an attack on the mother-child relationship (Thiara \& Humphreys, 2017). Perpetrators can undermine the relationship between mother and child as an act of coercive control (Buchanan \& Wendt, 2018). Hence, researching with children who have experienced domestic violence requires an understanding of the impacts of the violence and abuse on the mother-child relationship (Katz, 2019).

One approach to researching with children experiencing domestic violence is to triangulate the data with different voices and different perspectives. Research that has taken this approach attempts to situate the child's experience within their family relationships, the violence, their role in resistance, and the ways the child interacts with professionals and receives (or not), an appropriate response (Buckley et al., 2007; Eliffe \& Holt, 2019; Hogan and O'Reilly; 2007; Katz, 2019; Morris et al., 2012). In addition, understanding children's experiences is also about finding a balance between researching the child's negative life experience and researching the ways in which the same child experiences safety and resiliency and is an active agent in their engagement with the world, for themselves and for others (Eliffe \& Holt, 2019; Katz, 2019). An analytical framework that seeks to understand the child's actions and constraints within a broader relational context can facilitate more nuanced findings to inform tailored professional interventions.

Research has also shown that not all children experiencing domestic violence are doing poorly. For example, a metaanalysis of 118 studies by Kitzmann and colleagues (2003) found that 63 percent of children witnessing domestic violence were doing worse than those not witnessing domestic violence. However, the well-being of 37 percent was comparable or 
better than other children (Kitzmann et al., 2003). The phenomenon known as "resilience" (Rutter, 1985) has generally been referred to in the literature as the ability of individuals, families and communities to experience positive adaptation despite significant adversity (Herrman et al., 2011; Ungar, 2011; Walsh, 2006).

Ungar (2004) has argued that an approach to gleaning children's own resilience perspectives has been notably absent in the literature and that resilience research design should pursue an understanding of "the meaning children themselves construct phenomenologically" (2004, p. 353). To address this evidence gap and the notable absence of primary care research with children experiencing domestic violence, the SARAH project posed the following research questions:

- How do children and mothers understand children's safety and resilience in the context of domestic violence?

- How is children's safety realized in the context of domestic violence?

- How do children's voices inform a primary care response to domestic violence?

\section{Methods}

All of the children in the SARAH project were living with their mothers post-separation. However, some of the younger children continued to have regular court-ordered contact with their fathers. Sampling initially via the children's mothers reflected the need to understand unique risks to the child or mother in participating (e.g. father/ex-partner becomes aware of participation and becomes violent) and to empower women who had experienced coercive and controlling behaviors from an intimate partner by giving them an initial opportunity to reflect on the appropriateness of the research for their children. In accordance with University of Melbourne ethics approval of the project, there was no direct questioning of children about experiences of violence (unless they volunteered this information) as the sample were from a primary care population and the violence may not have been named within the family.

Written consent was gained from mothers initially and a model whereby children "assent" (agree) or "dissent" (disagree) to participate in the research was adopted (Alderson \& Morrow, 2011, p. 102; Morris et al., 2012, Mudaly \& Goddard, 2006). Children aged between 16 and 18 were able to provide written consent independently of their mother if they were assessed to be a "mature minor" (Sanci et al., 2004).

All participants provided written consent for themselves, or in the case of children, via their mothers for their information and images to be published. It was explained to participants that with a small sample size, anonymity could not be guaranteed. However, pseudonyms were used to minimize the likelihood of participants being identified. An initial risk assessment interview completed with all of the mothers resulted in an assessment of whether the risk was low, medium or high for each family to participate in the study (Morris et al.,

\section{Box I. The SARAH Project.}

\section{Methods}

- Mothers $(n=18)$ were recruited via purposive sampling (Patton, 2002) of a general practice population, from practice waiting rooms after completing a short questionnaire about their health and wellbeing.

- If the woman reported that she had been afraid of her partner/ex-partner and had children aged 8-25 years, she and her children were invited to participate

- Following an initial risk assessment interview with each mother, children and young people aged 8-24 years $(n=23)$ were recruited

- Minimum age of 8 years based on previous views of children in research (Mullender et al., 2002; Mudaly \& Goddard, 2006)

- Conducted individual semi-structured interviews about children's safety and resiliency

- Creative and play-based methods used when interviewing the younger children if they chose these including toys and an activity book that included fun writing and drawing tasks to elicit responses to each interview question.

- Short demographic survey completed for each family

- Conducted focus groups about appropriate health practitioner responses to children experiencing domestic violence.

2012). Of 19 families, 18 were ultimately able to participate. It was decided by the research team that it would be unsafe for one family to participate as the perpetrator of the violence still resided in the family home. The mother of the family was informed of this outcome and it was explained that this was based on an assessment of high risk for the family to participate which was the threshold for exclusion from the study.

It is well recognized that when undertaking research with women and children about domestic violence, the safety and emotional well-being of participants and the researcher is paramount (Maynard \& Purvis, 1994; Skinner et al., 2005). Accordingly, it is possible to address safety and well-being through identification of, and preparation for potential ethical issues (Farrell, 2005; Morris et al., 2012; Mullender et al., 2002; Mudaly \& Goddard, 2006). These precautions are symbolic of research about gendered violence, that balances the burdens and danger of such work with the hope and necessity for change (Lee \& Stanko, 2003; Skinner et al., 2005).

Collaboration with children about safety involves consideration of potential vulnerability and need for care and protection in the research process (Alderson \& Morrow, 2011). During the research process, acting with care (Noddings, 2003) meant prioritizing safe and respectful relationships in order for 
children to feel comfortable and to share their experiences. The child's trust in the research process includes a projected trust informed often by their altruistic motivations, that the research becomes a body of knowledge to benefit others.

Through a lens of care and doing no further harm, children were interviewed in places that were comfortable for them including their homes, the doctor's clinic they attended, at a university campus, and in one case, in a park near their workplace. They were able to have a support person with them if they chose. One young woman with a disability chose to have her mother in the interview with her. The children had regular opportunities for play, creativity, breaks, snacks and could answer the questions (or not) however they preferred.

Through a lens of care in communication each child was given the option to talk with the interviewer, or to write or draw on blank paper, or in an activity book that used a native Australian animal named Sarah, an echidna, to present the interview questions in ways that the child could relate to. For example, the echidna would tell the child a few things about herself first, then ask the child to describe a few things about themselves. Toys were also available during the interviews which children, including older children often held as they talked.

Younger children $>12$ years, preferred to use the activity book initially. They wrote or drew their answers, however as the interview progressed they would put the activity book aside and begin to talk more directly with the interviewer. This appeared to be an increasing in trust in the relationship with the researcher and with the process that enabled direct communication. All participants were offered the opportunity to review their transcripts and activity books prior to analysis, however when recontacted no one took up the offer to review.

\section{Analytical Framework}

The axiology of the SARAH project, that is the values inherent in all aspects of the research (Denzin \& Lincoln, 2005) were reflected in both the methodologies chosen and how they framed the research to ensure that it was both ethical and safe (Morris et al., 2012). In valuing the process of researching "with" rather than "for" or "to," feminist propositions that inform research with women and children about domestic violence were integrated with a children's participation rights discourse derived from the Convention on the Rights of the Child (UN General Assembly, 1989) and the "sociology of childhood" (Mayall, 1994; Qvortrup, 1991), that advocates for a child-centred approach when researching with children.

Hermeneutic phenomenology was chosen as the most aligned analytical approach. It can be described as a methodology that interprets life (hermeneutic) and lived experiences (phenomenology) (Van Manen, 1990). To move the research beyond seeking children's voices, the process of analysis needed to attend to interpreting the meaning of their experiences (Creswell, 2007; Denzin \& Lincoln, 2005; Tisdall et al., 2009). Hermeneutics (Heidegger, 1927/1962) is actioned in qualitative research through both the telling of the experience and exploring its relationship to theory. Maynard (1994) describes this as an interpretive and synthesizing process which connects experience to understanding. Cohen and colleagues explain that hermeneutic phenomenological analysis is "tricky" as it does not unfold as a linear process, despite references to linear descriptions of the method (2000, p. 71, Moustakas 1994). There is a need to continually re-order, reflect and rewrite throughout the stages of analysis to arrive at a critical final step in hermeneutic phenological analysis, that is useful knowledge or practical understanding and application (Packer \& Addison, 1989). A working model, as described in the findings below, linked the analysis to the real-world context of children's experiences and addressed the research gap in supporting potential health care interventions.

Hermeneutic phenomenological analysis was complemented by the moral philosophy of ethics of care and dialogical ethics from the feminist discourse that advocates a socially transformative struggle in which subjectivity and agency are key (Bell Hooks, 2004; Lather, 1991). In relation to domestic violence, this can be understood as the conditions in which women and children resist, overcome and recover from experiencing violence and abuse, which varies from person to person, is context-based and dependent on the resources they can garner.

The moral philosophy of ethics of care (Gilligan, 1993; Held, 2006; Noddings, 2003) has been described as a theory that focuses on care, compassion and relationships. Proponents seek "to maintain human connectedness and stress the importance of context and situational demands and responses that emphasize the moral sentiments of nurture and care" (Preston, 2001, p. 206).

Ethics of care is understood as a relational ethic (Gilligan, 1993) that encourages us to study the conditions that make it possible for caring relations to flourish (Groenhout, 2004). This promotes a sense of "feeling with" the other which is also known as empathy (Noddings, 2003, p. 28). Gilligan suggests that "ethics of care rests on a premise of non-violence" (1993, p. 174) and Noddings concurs with this idea to suggest that acting to prevent further abuse is informed by an ethic of caring (2003).These sentiments - empathy, non-violence, nurture and care needed to be realized in the research itself, as an antithesis to the participants lived experience of violence and abuse.

However, care ethicists (Groenhout, 2004; Sevenhuijsen, 1998) have argued the need for communicative or dialogical ethics (Koehn, 1998) to inform and complement a moral philosophy of care. Koehn (1998) explains that dialogical ethics contributes to the moral consideration of perspective and the need for thoughtfulness in the act of caring and being cared for. In the context of children who have experienced domestic violence, this premise becomes a critical piece in interpreting child voice. Koehn (1998) argues that dialogical ethics focuses on the interaction between people and their relationship to the issue of concern and to each other. Hence moral decisionmaking involves determining what should be done by taking into consideration different points of view and appraising them to determine a good (moral) decision or action. This includes 
Table I. Findings.

\begin{tabular}{|c|c|}
\hline Themes & Findings \\
\hline $\begin{array}{l}\text { Children's } \\
\text { Safety }\end{array}$ & $\begin{array}{l}\text { - Awareness of violence } \\
\text { - Named as violence and by whom } \\
\text { - Who provided care and protection }\end{array}$ \\
\hline $\begin{array}{l}\text { Children's } \\
\text { Resiliency }\end{array}$ & $\begin{array}{l}\text { - Trust in relationships } \\
\text { - Relational self-worth (children's } \\
\text { perspectives) } \\
\text { - Children are resilient despite adversity } \\
\text { (mothers' perspectives) }\end{array}$ \\
\hline $\begin{array}{c}\text { Children's } \\
\text { Agency }\end{array}$ & $\begin{array}{l}\text { - Distance from the perpetrator } \\
\text { - Awareness of danger or disruption in } \\
\text { parental relationship } \\
\text { - Modeling of safety in relationships } \\
\text { - Co-constructing family resiliency }\end{array}$ \\
\hline
\end{tabular}

the need to go beyond the carer's perception of the needs of those cared about or for, the need for active listening, eliciting of interpersonal truths and a coherent narrative.

Through the lens of dialogical ethics, other voices also informed the telling of the child's experience. For example, in addition to "child as participant," the study also sought the perspectives of the child's mother and siblings which complemented understanding of the child's experience.

Analysis of the data using hermeneutic phenomenology (Cohen et al., 2000; Moustakas, 1994) entailed taking an interpretive stance that moved between the literature about the phenomenon and the participant data set. Individual units of data that represented individual experiences, groupings of data and summaries of those groupings were made. The summaries reflected certain themes within the data set e.g. MotherChild: references within the data that highlighted aspects of the mother-child relationship, particularly communication between them and feelings toward each other.

Triangulating the data in this way has been employed in other studies (Eliffe \& Holt, 2019; Katz, 2019), and enabled exploration of the context of the child's familial relationships, and how they understood care and communication, and the violence and abuse experienced by them and others within their family. The findings illustrate these understandings in accordance with Koen's (1998) argument that dialogical ethics contributes to the moral consideration of perspective and the need for thoughtfulness in the act of caring and being cared for.

\section{Findings}

The findings of the Sarah Project are presented in Table 1. For the purposes of this paper, only the findings related to children's agency are explained in more detail and underpinned by a dialogical ethics analysis.

Through the lens of dialogical ethics, findings of the SARAH project illuminated the ways children and their mothers made meaning of their relationships and experiences and revealed children's thoughtful insights about their roles and

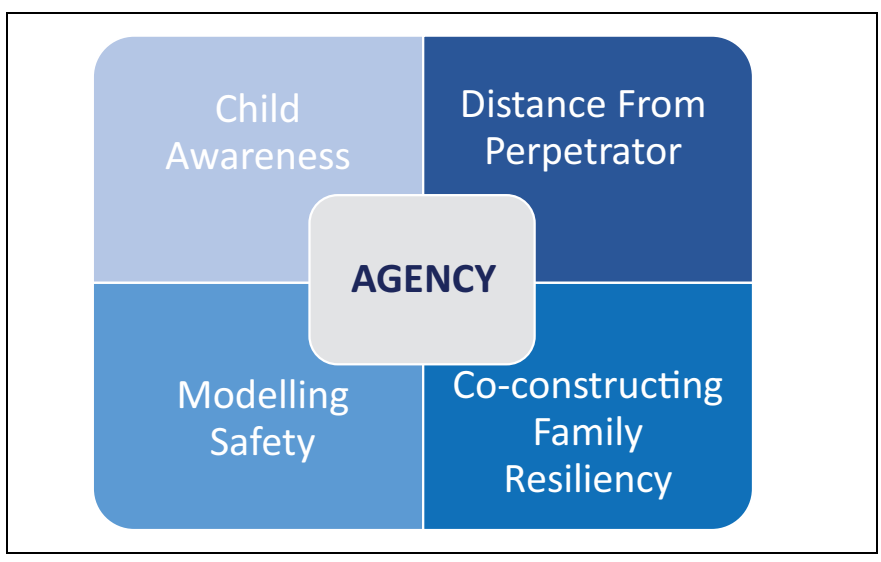

Figure I. Model of children's agency.

responsibilities in the family. The findings are focused around children's safety, children's resiliency and children's agency. We describe the factors that enabled children to experience agency within their relationships as a "Model of Children's Agency" (see Figure 1)

Model of children's agency. The four factors of the model that needed to be present included: that children had physical and emotional distance from their father post-separation, that the child had awareness of domestic violence or disruption in the parental relationship; that the child could observe and experience modeling of safety in relationships; and finally, that the child understood themselves as a co-constructor of family resiliency. Through a dialogical lens, the factors combined to reflect children's relational contexts and the roles they played as thinkers, observers, actors, and proactive change agents within their family relationships.

Of 18 families, the children in several families experienced one or more of these factors. However, in only three of the 18 families the children interviewed had all four factors present. Each of the factors was reflected in the way children understood themselves and their family situation. For example, Sophie described the way she and her brother's relationship to their father grew distant physically and emotionally over time when maintaining visits become much more one-sided. Their father had begun another relationship and had younger children with his new partner.

When we were younger it was probably you know, once a month. But then like as we got older into our teens, it was, you know once every three months or so. Kind of more school holidays. (Sophie, 20)

At 15 years old Sophie had decided she did not want to visit and stay with her father anymore. Her older brother also stopped visiting him at this time. Their father's disengagement from the relationship meant that he didn't pursue further contact. The children weighed up the role of their father in their lives and decided he no longer played a part. Their mother described how they no longer wished to talk about their father. In their actions 
and in their words (or lack thereof) these young people made a moral decision to withdraw from the relationship.

Relocation that was associated with a return to the locale of their mother's family of origin came with certain benefits for children. Even when there were family court orders for younger children to maintain contact with fathers long-distance, children who had relocated to country areas, interstate and overseas had less regular physical contact and this appeared to enable the mental space to appraise him and his role in their lives. Paternal extended family usually played a greater role when there was distance associated with contact visits. Mothers reported that this gave them some comfort that the children would be safer.

Over half of the children interviewed voiced their awareness of domestic violence or of disruption to the parental relationship. Through a dialogical lens it can be seen that this awareness served as a precursor to and was usually enhanced by communication and information about safety between mother and child. Sometimes this was in the midst of the father's violence:

I hated seeing Mum getting hurt, and stuff. I remember one time Mum was in my room, reading a book to me... and Dad came in, he was just spitting on her, and Mum just wasn't paying attention and then Dad went and got a cane stool, and ... went to throw it at us, so I like kind of jumped towards Mum to try and stop it hitting her. But he still threw it anyway, didn't stop him. I think it hit both of us. (Tahlia, 19)

Sometimes the awareness informed a need to be vigilant in the father's presence as Zoe explained:

He kinda bashed my mum when they broke up that night and like I'm worried that if I made him really, really mad he'd like, kinda bash me. (Zoe, 11)

Having some awareness of unrest or conflict in their parent's relationship spurred children to respond in some way to the situation even when they did not understand it to be domestic violence as brothers Max and Peter describe:

I ended up kinda being the in-between communicator and the mediator. (Max, 24)

My mum's emotions kind of let loose and... she was very emotional all the time... Um, yeah kind of needed support from us (children) and my grandmother. Even though I was eight I tried to help her in any way. (Peter, 18)

Children's reflections on their desire to help and care for their parents was commonly spoken about. At eight years old Peter was enacting care for his mother, given that he knew she was going through a very difficult time. This contrasts with the abuse she was experiencing from Peter's father.

A third factor in enabling children to experience agency was that the child could observe and experience the modeling safety in relationships.

Eleven year old George explained that he felt he could talk to, or seek comfort from his mother's friends, his uncles and

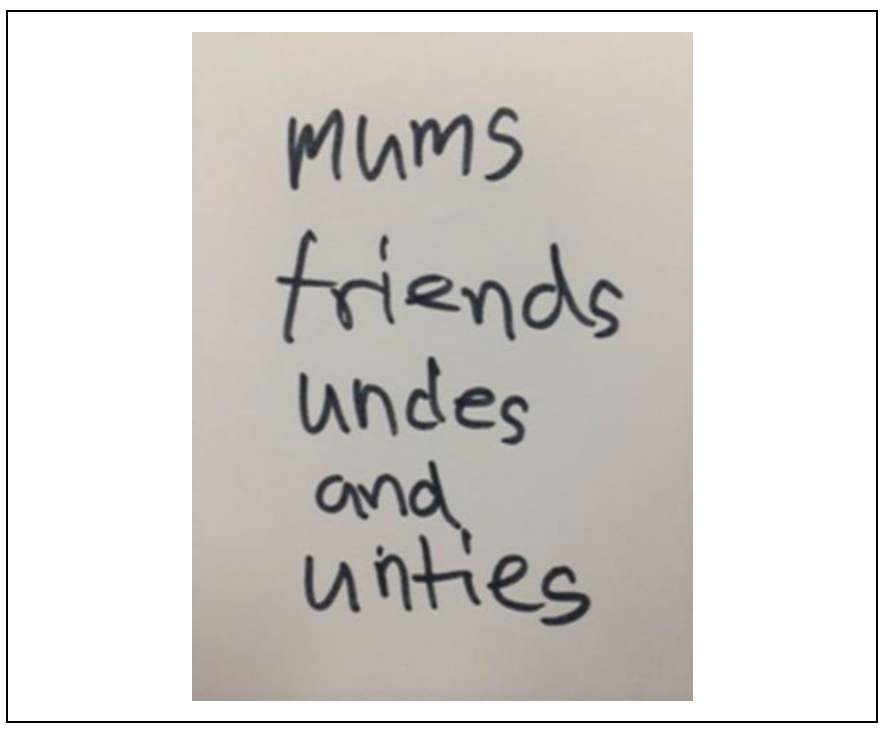

Figure 2. George's informal supports.

aunties (see Figure 2). While his father was a distant, somewhat scary figure in Paul's life, he identified his grandfather's modeling of safety in their relationship:

Yeah, my grandad. I used to go there a bit as well. And it was always just fun building stuff and helping around the house. (Paul, 17)

Through a dialogical lens, it can be seen that George and Paul rely on their own moral compass to reflect on the people in their lives that have led by example.

The final element of the "Model of Children's Agency," was a child's sense that they belonged to and were an active member of, a family that could remain intact or reform successfully despite adversity. This meant that the child was an active participant in co-constructing family resiliency. The concept of family resiliency is described in the literature in various ways that emphasize more or less the degree to which children reciprocate moral responsibility in families (Walsh, 2006). For 11 year old Runey who only spoke of stranger danger when he was interviewed, he had an equal role in being part of the glue with which his family stayed together:

Most of the time I'm pretty safe with my family. And yeah...' 'cause we all stick together.

When asked who was in his family, he replied:

Um, my sister Jane and my mum, Kelly and my mum's boyfriend. (Runey, 11)

The absence of Runey's father in this picture was telling, given that he still had regular contact with him. In contrast, Peter described a similar closeness within his family, that included a relationship with his father: 
How close our family is together... and that after what we have been through, that we're still, well us kids with Dad and his um family are still quite close and our immediate family here... are still quite close as well. (Peter, 18)

Peter's father was living overseas so the contact was less frequent and the boys in Peter's family were all now grown men who chose when and how they wanted to interact with their father. The ability to identify family closeness, who was in and who was out, implies an appraisal of family relationships. Runey's Mum's boyfriend made the cut, while Runey's father did not. At 11 years old, he is positioning himself away from his father. Peter however, is able to integrate his father into his life in a way that is safe and meaningful for him.

Ultimately, the findings revealed that children required all four factors: distance, awareness, modeling and coconstructing family resiliency, to be present to experience agency when negotiating safety in their relationships. Eleven year old Zoe's understanding of her family context exemplified the "Model of Children's Agency" which she explained in her dream recall:

I've had this dream but I know it's not true. We were at my house in the pool and then all of a sudden Nigel's (father) just come back in and he's asked for her (mum's) forgiveness and she just went "Yes." Then I got up and I said I'm staying here with Glen, which is my step-dad, he's like my real dad. I said "I'm staying here with Dad, I'm not leaving with you guys." And then Mum was like "Yes, please come with us." And I said "No, I'm not going back there" and then I swam off to the other side to go with Dad. (Zoe, 11)

She followed this story with the statement, "But I know that would never happen again to us. "Her conviction was based on understanding that she has the agency to negotiate the safety she needs in her relationships. What is interesting about Zoe's recall is that it reveals so much of an interpersonal truth and the moral reasoning that helps her arrive at a good decision for herself. She knows that she does not want to be with her father Nigel, she believes that her mother won't go back to him, however there is doubt based on her past experiences. Zoe identifies her step-father Glen as a safe person in her life and she actively chooses to stay with him.

While some factors of the "Model of Children's Agency" were experienced by all families who participated in the study, only three of the 18 families experienced all four factors. In addition, by virtue of reaching adulthood, some older children were able to experience agency in their personal (intimate partner) and professional relationships.

Summary. Through a dialogical lens children's meaning making of their relationships with each of their parents and with others in their lives illuminated their moral reasoning and decision making. Their thoughts and actions were often based on the care and protection they provided to others, and sometimes the care and protection they needed for themselves. Children and young adults who experienced the combined four elements of the "Model of Children's Agency" had agency to position themselves safely in relation to others. The model does not therefore deny children's relationships with their fathers where these can be experienced as safe, instead it supports increased opportunities for children to form safe and meaningful bonds with broader family and friends. With each element of the model in place, children were able to find ways to move beyond the violence and lack of agency they had experienced and into supportive contexts that facilitated agency in relationships within broader interpersonal relationships, and sometimes in relationships with their fathers as well.

\section{Discussion}

The SARAH project has demonstrated that when children are able to share their experiences through safe and ethical research focused on children's safety and resilience, there is greater opportunity to move beyond the negative impacts of domestic violence and to explore how children experience agency in their relationships. The study used ethics of care, and in particular dialogical ethics (Held, 2006; Koehn, 1998) to research with and analyze children's experiences of safety and resiliency in the context of domestic violence and found that four factors contributed to children's agency in negotiating safety in their relationships.

The factors were reflected in the "Model of Children's Agency" and included children's physical and emotional distance from the perpetrator. As Bancroft and Silverman (2002) have argued, fathers who perpetrate domestic violence are often less engaged in their parenting role than other fathers. Children and young people in Lamb, Humphreys and Hegarty's (2018, p. 168) study wanted their fathers "to make more of an effort to positively co-parent with their mothers." Hence, while children and mothers may move away and prefer less contact with violent fathers, the men themselves may wane in their desire to see and spend time with their children, particularly as the children move into adolescence and fathers move on to new partners and new families (the authors acknowledge that unfortunately men often go on to perpetrate violence in these new relationships).

Katz (2019) described the closeness or otherwise of relationships between children and their mothers in the context of domestic violence. She explained that close relationships featured children's awareness of their father's violence and abuse. Similarly, using a dialogical lens the SARAH project demonstrated that when children were in communication with their mother about safety, they had a greater awareness of their father's violence.

Dialogical ethics is a tool through which to examine how children appraise their parents and the relationships they have with each parent. When there is violence perpetrated by one parent against the other, children need opportunities to observe and experience modeling of safety in relationships so they can be supported and safe and learn how to conduct their own safe and respectful relationships into adulthood (Holt et. al., 2008; Mullender, 2002). 
When children in the SARAH project acknowledged the people that they could rely on and trust, they were able to talk about those relationships in ways that afforded the person a key role as confidante, someone to have fun with, as their "Dad" in the case of non-violent step-fathers and as someone they just wanted to be around. As a protective factor, safe interpersonal relationships with extended family and family friends have much to offer these children.

A final factor in the "Model of Children's Agency" is family resiliency which reflects a dialogical process that realizes "shared beliefs and narratives that foster a sense of coherence, collaboration, competence and confidence" (Walsh, 1996, p. 261). As Katz (2019, p. 17) explains, "mother-child relationships were not maintained by mothers alone. Rather, they were jointly maintained by mothers and children." The child's opinion of their mother was a key determinant of the closeness or otherwise the mother-child relationship.

More broadly, children in the SARAH project who considered that they were part of a resilient family felt that they were "held" by a well-integrated informal support network of extended family and community.

\section{Conclusion}

Underpinned by child-centred, ethical research methods including hermeneutic phenomenological analysis and the lenses of ethics of care and dialogical ethics, an understanding of children's safety and resilience in the context of domestic violence has established four factors that when combined, facilitate children's agency to negotiate their safety in relationships. The "Model of Children's Agency" defines optimal characteristics that together work to build a relational network of safety around the child and demonstrates children's role as thinkers, observers, actors, and proactive change agents within their family.

As an example of dialogical ethics-informed domestic violence research with children, the SARAH project was informed by the child's voice and the voices of others close to them, their mother and siblings. Through an ethics of care lens, the interviewer enabled participants to share in ways that were safe and comfortable for them, to understood the child's role in caring for, and protecting themselves and others in the family, including their mothers. It also revealed the role of significant others such as grandparents as safe role models for these children. However, through the lens of dialogical ethics (Koehn, 1998), the findings go further to also reveal the child's own moral reasoning in appraising their relationships and demonstrates how this is communicated through the child's words, actions and meaning-making.

Researchers in this field should consider using a dialogicalinformed analytical framework as a critical tool in moving beyond voice and into contextual relational understanding. Health and welfare practitioners and policy makers can use the "Model of Children's Agency" to inform their design and implementation of domestic violence interventions with children to ensure a focus on children's agency to negotiate their safety in relationships.

\section{Acknowledgment}

Australian Research Council APAI Linkage Grant: University of Melbourne and Berry Street.

\section{Declaration of Conflicting Interests}

The author(s) declared no potential conflicts of interest with respect to the research, authorship, and/or publication of this article.

\section{Ethics Approval}

No. 0932493 Medicine, Dentistry and Health Sciences Human Research Ethics Committee, University of Melbourne, Australia

\section{Funding}

The author(s) disclosed receipt of the following financial support for the research, authorship, and/or publication of this article: The lead author received an Australian Postgraduate Award Industry Scholarship to undertake this $\mathrm{PhD}$ research.

\section{ORCID iD}

Anita Morris (D) https://orcid.org/0000-0003-0352-0979

\section{References}

Alderson, P., \& Morrow, V. (2011). The ethics of research with children and young people: A practical handbook. SAGE Publications.

Bagshaw, D., Brown, T., Wendt, S., Campbell, A., McInnes, E., Tinning, B., Batagol, B., Sifris, A., Tyson, D., Baker, J., \& Fernandez Arias, P.(2010). Family violence and family law in Australia: The experiences and views of children and adults from families who separated post 1995 and post 2006 (Vol. 1). Attorney General's Department, Commonwealth of Australia.

Bair-Merritt, M., Blackstone, M., \& Feudtner, C. (2006). Physical health outcomes of childhood exposure to intimate partner violence: A systematic review. Paediatrics, 117(2), 278-290.

Bancroft, L., Richie, D., \& Silverman, J. G. (Eds.). (2002). Assessing risk to children from batterers. The Batterer as Parent. Addressing the Impact of Domestic Violence on Family Dynamics (pp. 198-214). Sage.

Bedi, G., \& Goddard, C. (2007). Intimate partner violence: What are the impacts on children? Australian Psychologist, 42(1), 66-77.

Bell Hooks. (2004). Choosing the margin as a space of radical openness. In S. Harding (Ed.), The feminist standpoint theory reader: Intellectual and political controversies (pp. 153-159). Routlege.

Bergström, M. (1983). De glömda barnen [The forgotten children]. Socionomen, 1983(2), 6-7.

Broberg, A., Almqvist, L., Almqvist, K., Cater, A. K., \& Eriksson, M. (2010). Support to children who have experienced violence against their mother: Preliminary results from a national evaluation study. Department of Psychology, University of Gothenburg.

Buchanan, F., \& Wendt, S. (2018). Opening doors: Women's participation in feminist studies about domestic violence. Qualitative Social Work, 17(6), 762-777. 
Buckley, H., Holt, S., \& Whelan, S. (2007). Listen to me! Children's experiences of domestic violence. Child Abuse Review, 16(5), 296-310.

Callaghan, J. E., Alexander, J. H., Sixsmith, J., \& Fellin, L. C. (2018). Beyond "witnessing": Children's experiences of coercive control in domestic violence and abuse. Journal of Interpersonal Violence, 33(10), 1551-1581.

Cohen, M. Z., Kahn, D. L., \& Steeves, R. H. (2000). Hermeneutic phenomenological research: A practical guide for nurse researchers (Vol. 2). Sage Publications.

Creswell, J. W. (2007). Qualitative inquiry and research design: Choosing among five approaches (2nd ed.). Sage Publications.

DeBoard-Lucas, R. L., \& Grych, J. H. (2011). Children's perceptions of intimate partner violence: Causes, consequences, and coping. Journal of Family Violence, 26(5), 343-354.

Denzin, N. K., \& Lincoln, Y. S. (Eds.). (2005). The Sage handbook of qualitative research (3rd ed.). Sage Publications.

Edleson, J. L. (1999). Children's witnessing of adult domestic violence. Journal of Interpersonal Violence, 14(8), 839-870.

Elbow, M. (1982). Children of violent marriages: The forgotten victims. Social Casework, 63, 465-471.

Elliffe, R., \& Holt, S. (2019). Reconceptualizing the child victim in the police response to domestic violence. Journal of Family Violence, 34, 589-600.

Eriksson, M., \& Näsman, E. (2010). Interviews with children exposed to violence. Children \& Society, 26(1), 63-73.

Evans, S., Davies, C., \& DiLillo, D. (2008). Exposure to domestic violence: A meta-analysis of child and adolescent outcomes. Aggression and Violent Behavior, 13(2), 131-140.

Farrell, A. (2005). Ethical research with children. Open University Press.

Feder, G., Ramsey, J., Dunne, D., Rose, M., Arsene, C., Norman, R., Kuntze, S., Spencer, A., Bacchus, L., Hague, G., \& Taket, A. (2009). How far does screening women for domestic (partner) violence in different health care settings meet criteria for a screening programme? Systematic reviews of nine UK National Screening Committee criteria. Health Technology Assessment, 13(16), $1-113$.

Finkelhor, D., Turner, H., Hamby, S., \& Ormrod, R. (2011). Polyvictimization: Children's exposure to multiple types of violence, crime, and abuse. U.S. Department of Justice.

Gilligan, C. (1993). In a different voice: Psychological theory and women's development. Harvard University Press.

Groenhout, R. E. (2004). Connected lives: Human nature and an ethics of care. Rowman \& Littlefield Publishers Inc.

Groves, B. M. A., Zuckerman, B., Marans, S., \& Cohen, D. J. (1993). Silent victims: Children who witness violence. JAMA, 269(2), 262-264.

Heidegger, M. (1962). Being and time. (J. Macquarie \& E. Robinson, Trans.). New Harper and Row. (Original work published in 1927)

Held, V. (2006). The ethics of care: Personal, political, and global. Oxford University Press.

Herrman, H., Stewart, D. E., Diaz-Granados, N., Berger, E. L., Jackson, B., \& Yuen, T. (2011). What is resilience? Canadian Journal of Psychiatry, 56(5), 258-265.
Hogan, F., \& O'Reilly, M. (2007). Listening to children: Children's stories of domestic violence. Dublin Government Publications.

Holden, G. W. (2003). Children exposed to domestic violence and child abuse: Terminology and taxonomy. Clinical Child \& Family Psychology Review, 6(3), 151-160.

Holt, S., Buckley, H., \& Whelan, S. (2008). The impact of exposure to domestic violence on children and young people: A review of the literature. Child Abuse \& Neglect, 32(8), 797-810.

Houghton, C. (2015). Young people's perspectives on a participatory ethics: Agency, power and impact in domestic abuse research and policy-making. Child Abuse Review 24, 235-248.

Howarth, E, Moore, T. H. M., \& Stanley, N. (2018). Towards an ecological understanding of readiness to engage with interventions for children exposed to domestic violence and abuse: Systematic review and qualitative synthesis of perspectives of children, parents and practitioners. Health \& Social Care in the Community, 27, 271-292. https://doi.org/10.1111/hsc.12587

Katz, E. (2016). Beyond the physical incident model: How children living with domestic violence are harmed by and resist regimes of coercive control. Child Abuse Review, 25(1), 46-59. https://doi. org/10.1002/car.2422

Katz, E. (2019). Coercive control, domestic violence, and a five-factor framework: Five factors that influence closeness, distance, and strain in mother-child relationships. Violence Against Women, 1-25. https://doi.org/10.1177/1077801218824998

Kitzmann, K. M., Gaylord, N. K., Holt, A. R., \& Kenney, E. D. (2003). Child witnesses to domestic violence: A meta-analytic review. Journal of Consulting and Clinical Psychology, 71(2), 339-352.

Koehn, D. (1998). Rethinking feminist ethics: Care, trust and empathy. Routledge.

Kolar, K. R., \& Davey, D. (2007). Silent victims: Children exposed to family violence. The Journal of School Nursing, 23(2), 86-91.

Laing, L. (2000). Children, young people and domestic violence. Australian Domestic and Family Violence Clearinghouse, 2, 1-28.

Lamb, K., Humphreys, C., \& Hegarty, K. (2018). "Your behaviour has consequences": Children and young people's perspectives on reparation with their fathers after domestic violence. Children and Youth Services Review, 88, 164-169.

Lather, P. A. (1991). Getting smart: feminist research and pedagogy with/in the postmodern. Routledge.

Lee, R., \& Stanko, E. (2003). Researching violence: essays on methodology and measurement. Routledge.

Lieten, G. K. (2008). Children, structure and agency: Realities across the developing world. Routledge.

MacMillan, H. L., Wathen, C. N., \& Varcoe, C. M. (2013). Intimate partner violence in the family: Considerations for children's safety. Child Abuse \& Neglect, 37(12), 1186-1191.

Mayall, B. (1994). Children's childhoods observed and experienced. Falmer Press.

Maynard, M., \& Purvis, J. (Eds.). (1994). Researching women's lives from a feminist perspective. Taylor \& Francis.

McGee, C. (2000). Childhood experiences of domestic violence. Jessica Kingsley.

Morris, A., Hegarty, K., \& Humphreys, C. (2012). Ethical and safe: Research with children about domestic violence. Research Ethics, $8(2), 125-139$. 
Moustakas, C. E. (1994). Phenomenological research methods. Sage Publications.

Mudaly, N., \& Goddard, C. R. (2006). The truth is longer than a lie: Children's experiences of abuse and professional interventions. Jessica Kingsley Publishers.

Mullender, A., Hague, G., Imam, U., Kelly, L., Malos, E., \& Regan, L. (2002). Children's perspectives on domestic violence. Sage Publications.

Neale, B., \& Flowerdew, J. (2007). New structures, new agency: The dynamics of child-parent relationships after divorce. International Journal of Children's Rights, 15(1), 25-42.

Noble-Carr, D, Moore, T., \& McArthur, M. (2019). Children's experiences and needs in relation to domestic and family violence: Findings from a meta-synthesis. Child \& Family Social Work. 1-10. https://doi.org/10.1111/cfs. 12645

Noddings, N. (2003). Caring: A feminine approach to ethics \& moral education (2nd ed.). University of California Press.

Olaya, B., Ezpeleta, L., de la Osa, N., Granero, R., \& Doménech, J. M. (2010). Mental health needs of children exposed to intimate partner violence seeking help from mental health services. Children and Youth Services Review, 32(7), 1004-1011.

Överlien, C., \& Hydén, M. (2009). Children's actions when experiencing domestic violence. Childhood, 16(4), 479-496.

Overlien, C. (2010). Children exposed to domestic violence: Conclusions from the literature and challenges ahead. Journal of Social Work, 10(1), 80-97.

Øverlien, C., \& Aas, G. (2016). The police patrols and children experiencing domestic violence. Police Practice and Research, 17(5), 434-447.

Packer, M., \& Addison, R. (1989). Entering the circle: Hermeneutic investigation in psychology. State University of New York Press.

Peled, E. (1998). The experience of living with violence for preadolescent children of battered women. Youth \& Society, 29(4), 395-430.

Perry, B. D. (2001). The neurodevelopmental impact of violence in childhood. In D. Schetky \& E. P. Benedek (Eds.), Textbook of child and adolescent forensic psychiatry (pp. 221-238). American Psychiatric Press.

Preston, N. (Ed.). (2001). Understanding ethics (2nd ed.). Federation Press.

Qvortrup, J. (Ed.). (1991). Childhood as a social phenomenon: An introduction to a series of national reports (2nd ed.). European Centre for Social Welfare Policy and Research.

Rutter, M. (1985). Resilience in the face of adversity: Protective factors and resistance to psychiatric disorder. British Journal of Psychiatry, 147(6), 598-611.
Sanci, L. A., Sawyer, S. M., Weller, P. J., Bond, L. M., \& Patton, G. C. (2004). Youth health research ethics: time for a mature-minor clause? Medical Journal of Australia, 180(7), 336-338.

Sevenhuijsen, S. (1998). Citizenship and the ethics of care: Feminist considerations on justice, morality, and politics (L. Savage, Trans.). Routledge.

Skinner, T., Hester, M., \& Malos, E. (Eds.). (2005). Researching gender violence: Feminist methodology in action. Willan Publishing.

Stanley, N., Miller, P., Foster, H. R., \& Thomson, G. (2010). Children and families experiencing domestic violence: Police and children's social services' responses. The National Society for the Prevention of Cruelty to Children.

Stanley, N., Miller, P., Foster, H. R., \& Thomson, G. (2011). Children's experiences of domestic violence: developing an integrated response from police and child protection services. Journal of Interpersonal Violence, 26(12), 2372-2391.

Taft, A., Broom, D. H., \& Legge, D. (2004). General practitioner management of intimate partner abuse and the whole family: qualitative study. BMJ, 328(7440), 618.

Thiara, R. K., \& Humphreys, C. (2017). Absent presence: the ongoing impact of men's violence on the mother-child relationship. Child \& Family Social Work, 22(1), 137-145.

Tisdall, E. K., Davis, J. M., \& Gallagher, M. (2009). Researching with children and young people: Research design, methods and analysis. Sage Publications.

Ungar, M. (2004). A Constructionist discourse on resilience: Multiple contexts, multiple realities among at-risk children and youth. Youth \& Society, 35(3), 341-365.

Ungar, M. (2011). The Social ecology of resilience: Addressing contextual and cultural ambiguity of a nascent construct. American Journal of Orthopsychiatry, 81(1), 1-17.

UN General Assembly, Convention on the Rights of the Child. (20 November 1989). United Nations. Treaty Series, 1577, 3. Retrived September 1, 2019, from https://www.refworld.org/docid/3ae6b3 8f0.html

Van Manen, M. (1990). Researching lived experience: Human science for an action sensitive pedagogy. State University of New York Press.

Walsh, F. (1996). The concept of family resilience: Crisis and challenge. Family Process, 35(3), 261-281.

Warrier, S., Williams-Wilkins, B., Pitt, E., Reece, R. M., Groves, B. M., Lieberman, A. F., \& Mcnamara, M. (2002). 'Culturally competent responses' and 'Children: Hidden victims'. Violence Against Women, 8(6), 661-686. 


\section{University Library}

\section{- M M N E R VA A gateway to Melbourne's research publications}

Minerva Access is the Institutional Repository of The University of Melbourne

Author/s:

Morris, A;Humphreys, C;Hegarty, K

Title:

Beyond Voice: Conceptualizing Children's Agency in Domestic Violence Research Through a Dialogical Lens

Date:

2020-10-14

Citation:

Morris, A., Humphreys, C. \& Hegarty, K. (2020). Beyond Voice: Conceptualizing Children's Agency in Domestic Violence Research Through a Dialogical Lens. INTERNATIONAL JOURNAL OF QUALITATIVE METHODS, 19, https://doi.org/10.1177/1609406920958909.

Persistent Link:

http://hdl.handle.net/11343/252236

License:

cc-by-nc 